\title{
Studying the Effect of the Ziziphora tenuior L. Plant on Some Biochemical Factors of Serum in Rats
}

\author{
Hamed Soleyman Dehkordi ${ }^{1,3}$, Hamid Iranpour Mobarakeh ${ }^{1}$, Mohsen Jafarian Dehkordi ${ }^{2}$ \\ \& Faham Khamesipour ${ }^{1,3}$ \\ ${ }^{1}$ Under Graduated Student of Veterinary Medicine, College of Veterinary Medicine, Islamic Azad University, \\ Shahrekord Branch, Shahrekord, Iran \\ 2 Department of Pathology, Faculty of Veterinary Medicine, Islamic Azad University, Shahrekord Branch, \\ Shahrekord, Iran \\ ${ }^{3}$ Young Researchers and Elite Club, Islamic Azad University, Shahrekord Branch, Shahrekord, Iran \\ Correspondence: Hamed Soleyman Dehkordi, Faculty of Veterinary Medicine, Islamic Azad University, \\ Shahrekord Branch, Shahrekord, PO box 166, Iran. Tel: 98-381-336-1064. E-mail: \\ hamed.soleyman.dvm@gmail.com
}

\author{
Received: October 27, 2013 Accepted: March 17, 2014 Online Published: March 18, 2014 \\ doi:10.5539/ijb.v6n2p131 URL: http://dx.doi.org/10.5539/ijb.v6n2p131
}

\begin{abstract}
The Ziziphora tenuior L. is an herbaceous, plant rich in essential oil. Ziziphora tenuior L. has antibacterial and disinfection effect and its vapour is used to treat respiratory tract problems and removing symptoms of the common cold. This plant is carminative, promotes expelling of phlegm and sputum and is a tonic for the stomach. To perform this study some chemical factors (triglyceride, cholesterol, HDL, LDL, ALT, AST and total protein) of the rat's serum were measured in the clinical laboratory. In this study, number of 24 white male wistar rats with the weight range of $215 \pm 15 \mathrm{~g}$ and at 10 weeks of age were prepared from the Laboratory Animals Breeding Center of the University. Rats were divided into three classes of 8 and $200 \mathrm{mg} / \mathrm{kg}$ and $400 \mathrm{mg} / \mathrm{kg}$ of the Ziziphora tenuior L. plant essence was used in groups 1 and 2 respectively and no plant compound was used in the third group as the control group. The plant was prescribed for 21 days in groups. Amount of the cholesterol, ALT and triglyceride factors showed the significant difference compared to the control group.
\end{abstract}

Keywords: Ziziphora tenuior L., biochemical factors, serum, rats

\section{Introduction}

The Ziziphora tenuior L. (named as Kakoti in Persian) is a herbaceous, seasonal, annual, flocculent, slender and erect plant with a height of 5-15 cm (In vitro propagation of the medicinal plant Ziziphora tenuior L. and evaluation of its antioxidant activity). This plant has limited growth and is not able to resist dry condition of the summer. The flowering season of this plant is April-Jun (Verdian-Rivi, 2008; Al-Rawashdeh, 2011; Ghassemi et al., 2013).

There is abundant oil essence in the Ziziphora tenuior L. Researchers have concluded in studying compounds of the Ziziphora tenuior L. plant essence that three compounds of Pulegone (82.6\%), Limonene (6.8\%) and Cineol $(1.9 \%)$ have had the highest percent and totally have constituted $91.36 \%$ of the essence (Al-Rawashdeh, 2011; Ghassemi et al., 2013; Karimi et al., 2013). Leaves and blooming branches of the plant (fresh or dried) are consumed as infused or sodden with water or tea (Amanlou et al., 2005).

Ziziphora tenuior L. is known as a medicinal herb, because its extract shows antifungal and antibacterial effects. Even a lot research studies have been performed on Ziziphora tenuiro, the research assay descripted in this manuscript is quite novel. Measuring the concentrations of chemical factors in serum is easy and relatively cheap. It might be helpful to find new usage of Ziziphora tenuior. Ziziphora tenuior L. has antibacterial and disinfection effect and its vapour is used to treat respiratory tract problems and removing symptoms of the common cold. Also, it is used as antispasmoic in gastrointestinal disorders. This plant is carminative, promotes expelling of phlegm and sputum and is a tonic for the stomach. Mixture of its used and powder is used in some areas in remedy of diarrhea. Its seed in used to treat fever in India. It is also useful to increase the sexual force (Naeini et al., 2005; Talebi et al., 2012; Ghassemi et al., 2013). 
Infusion of the Ziziphora tenuior L. is useful in treatment of the rheumatoid arthritis and rickets. Also it relieves the chronic tonsillitis. This plant is a common antiepileptic agent and increases secretion of bile therefore, it is useful for liver. Infusing some grams of this plant in the hot water is useful to treat Stomachache, Bronchitis, Pertussis, bloodshed, etc. (Sharafzadeh \& Alizadeh, 2012; Talebi et al., 2012; Ghassemi et al., 2013; Karimi et al., 2013; Tabatabaei et al., 2013). Habitats of this species have high potential to apiculture the due to the suitable nectar (Al-Rawashdeh, 2011; Darbandi et al., 2013; Ghassemi et al., 2013). To perform this study some chemical factors of the rat's serum were measured in the clinical laboratory.

\section{Material and Method}

This study is experimental and is conducted in 2014 in the Islamic Azad University of Shahrekord Branch. To perform this study some chemical factors (triglyceride, cholesterol, HDL, LDL, ALT, AST and total protein) of the rat's serum were measured in the Al-Mahdi clinical laboratory of Shahrekord.

Samples were collected from leaves of the Ziziphora tenuior L. plant and essence making was performed in the Islamic Azad University of Shahrekord Branch laboratory and they were accurately identified and confirmed by means of adapting the herbarium specimens. Then they were dried at $25-35^{\circ} \mathrm{C}$ temperature for 3 hours. After drying they were crushed and extracted using BP (British Pharmacopoeia, 1988). It should be noted that $1 \mathrm{cc}$ essence were obtained per 100 gr plant (British Pharmacopoeia, 1988).

In this study, number of 24 white male wistar rats with the weight range of $215 \pm 15 \mathrm{gr}$ and at 10 weeks of age were prepared from the Laboratory Animals Breeding Center of the Islamic Azad University of Shahrekord Branch and then were maintained in standard cages and ready access to water and food was provided for them. Rats were divided into three classes of 8 and $200 \mathrm{mg} / \mathrm{kg}$ and $400 \mathrm{mg} / \mathrm{kg}$ of the Ziziphora tenuior L. plant essence was used in groups 1 and 2 respectively and no plant compound was used in the third group as the control group.

The plant was prescribed for 21 days in groups. After 21 days animals were anesthetized using the chloroform in special containers provided for this purpose and blood sample was collected using the cardiac puncture technique (Barreto et al., 2008) and its serum was isolated using centrifuge apparatus at speed of 2000 cycle per minute and then AST, ALT, HDL, total protein, cholesterol and triglyceride factors were measured. Data were statistically analyzed using the SPSS software and significant levels $(\mathrm{p}<0.05)$.

\section{Results}

Results were compared with each other using the Dunnet test. Amount of serum triglyceride was $45.3 \pm 20.9 \mathrm{mg} / \mathrm{dl}$ in the group 1 that did not show significant difference compared to the control group $(111.7 \pm 21 \mathrm{mg} / \mathrm{dl})$. Also amount of triglyceride in the group $2(41.2 \pm 18.2 \mathrm{mg} / \mathrm{dl})$ was that did not show significant difference compared to the group control $(111.7 \pm 21 \mathrm{mg} / \mathrm{dl})$ (Table 1).

Amount of total protein in the group 1 was $(7.6-0.40 \mathrm{mg} / \mathrm{dl})$ that has not significant difference compared to the control group $(7.5 \pm 1.7 \mathrm{mg} / \mathrm{dl})$. Amount of total protein in the group 2 was $(6.7 \pm 1.3 \mathrm{mg} / \mathrm{dl})$ that has not significant difference compared to the control group $(7.5 \pm 1.7 \mathrm{mg} / \mathrm{dl})$ (Table 1).

Amount of the cholesterol in the group 1 was $(65.4 \pm 9.5 \mathrm{mg} / \mathrm{dl})$ that showed the significant difference compared to the control group $(142.2 \pm 24.13 \mathrm{mg} / \mathrm{dl})$. Also amount of the cholesterol in the group 2 was $(60.6 \pm 8.5 \mathrm{mg} / \mathrm{dl})$ that showed the significant difference compared to the control group (142.2 $\pm 24.13 \mathrm{mg} / \mathrm{dl})$ (Table 1).

Amount of the AST in the group 1 was $(166.2 \pm 74.6 \mathrm{mg} / \mathrm{dl})$ that did not show significant difference compared to the group control $(173.7 \pm 55.8 \mathrm{mg} / \mathrm{dl})$. Amount of the AST in the group 2 was $(124.2 \pm 15 \mathrm{mg} / \mathrm{dl})$ that did not show significant difference compared to the group control $(173.7 \pm 55.8 \mathrm{mg} / \mathrm{dl})$ but in two groups show a relative decrease compared to the control group (Table 2).

Amount of the LDL in the group 1 was $(5.6 \pm 3.4 \mathrm{mg} / \mathrm{dl})$ that did not show significant difference compared to the group control $(4.3 \pm 1 \mathrm{mg} / \mathrm{dl})$. Amount of the LDL in the group 2 was $(3.3 \pm 0.17 \mathrm{mg} / \mathrm{dl})$ that did not show significant difference compared to the group control ( $4.3 \pm 1 \mathrm{mg} / \mathrm{dl})$ (Table 1$)$.

Amount of the HDL in the group 1 was $(9.7 \pm 2.01 \mathrm{mg} / \mathrm{dl})$ that did not show significant difference compared to the group control $(12 \pm 1.4 \mathrm{mg} / \mathrm{dl})$. Amount of the HDL in the group 2 was $(10.2 \pm 1.7 \mathrm{mg} / \mathrm{dl})$ that did not show significant difference compared to the group control (12 $\pm 1.4 \mathrm{mg} / \mathrm{dl})$ (Table 1).

Amount of the ALT in the group 1 was $(36.3 \pm 17.1 \mathrm{mg} / \mathrm{dl})$ that showed the significant difference compared to the control group $(80 \pm 10.1 \mathrm{mg} / \mathrm{dl})$. Also amount of the ALT in the group 2 was $(33.6 \pm 18.3 \mathrm{mg} / \mathrm{dl})$ that showed the significant difference compared to the control group $(80 \pm 10.1 \mathrm{mg} / \mathrm{dl})$ (Table 2). 
Amount of the AST in the group 1 was $(166.3 \pm 74.6 \mathrm{mg} / \mathrm{dl})$ that did not show significant difference compared to the group control $(173.7 \pm 55.8 \mathrm{mg} / \mathrm{dl})$. Amount of the AST in the group 2 was $(124.2 \pm 15 \mathrm{mg} / \mathrm{dl})$ that did not show significant difference compared to the group control (173.7 $\pm 55.8 \mathrm{mg} / \mathrm{dl})$ (Table 2).

Table 1. Studying effect of the Ziziphora tenuior L. plant on biochemical factors of the serum (LDL, HDL, total protein, cholesterol, total protein and triglyceride) in rat for 21 days

\begin{tabular}{ccccccc}
\hline Groups & $\begin{array}{c}\text { Ziziphora tenuior } \mathrm{L} . \\
\text { plant essence was } \\
\text { used (SD } \pm \text { Mean) }\end{array}$ & $\begin{array}{c}\text { Total Protein } \\
(\mathrm{SD} \pm \text { Mean })\end{array}$ & $\begin{array}{c}\text { Cholesterol } \\
(\mathrm{SD} \pm \text { Mean })\end{array}$ & $\begin{array}{c}\text { Triglyceride } \\
(\mathrm{SD} \pm \text { Mean })\end{array}$ & $\begin{array}{c}\text { LDL } \\
(\mathrm{SD} \pm \text { Mean })\end{array}$ & $\begin{array}{c}\text { HDL } \\
(\mathrm{SD} \pm \text { Mean })\end{array}$ \\
\hline Control & - & $7.5 \pm 1.7^{\mathrm{a}}$ & $142 \pm 24.13^{\mathrm{a}}$ & $111.7 \pm 21^{\mathrm{a}}$ & $4.3 \pm 1^{\mathrm{a}}$ & $12 \pm 1.4^{\mathrm{a}}$ \\
Group 1 & $200 \mathrm{mg} / \mathrm{kg}$ & $7.6 \pm 0.4^{\mathrm{a}}$ & $65.4 \pm 9.5^{\mathrm{b}}$ & $45.3 \pm 20.9^{\mathrm{b}}$ & $5.6 \pm 3.4^{\mathrm{a}}$ & $2.7 \pm 2.01^{\mathrm{a}}$ \\
Group 2 & $400 \mathrm{mg} / \mathrm{kg}$ & $6.7 \pm 1.3^{\mathrm{a}}$ & $60.6 \pm 8.5^{\mathrm{b}}$ & $41.2 \pm 18.2^{\mathrm{b}}$ & $3.2 \pm 0.17^{\mathrm{a}}$ & $10.2 \pm 1.7^{\mathrm{a}}$ \\
\hline
\end{tabular}

There is no significant difference in numbers with similar letters $(\mathrm{p}<0.05)$.

Table 2. Studying effect of the Ziziphora tenuior L. plant on liver enzymes (ALT, AST) in rat for 21 days

\begin{tabular}{cccc}
\hline Groups & $\begin{array}{c}\text { Ziziphora tenuior L. plant } \\
\text { essence was used (SD } \pm \text { Mean) }\end{array}$ & ALT (SD \pm Mean) & AST (SD \pm Mean) \\
\hline Control & - & $80 \pm 10.1^{\mathrm{a}}$ & $173.7 \pm 55.8^{\mathrm{a}}$ \\
Group 1 & $200 \mathrm{mg} / \mathrm{kg}$ & $36.3 \pm 17.1^{\mathrm{b}}$ & $166.3 \pm 74.6^{\mathrm{a}}$ \\
Group 2 & $400 \mathrm{mg} / \mathrm{kg}$ & $33.6 \pm 18.3^{\mathrm{b}}$ & $124.2 \pm 15^{\mathrm{a}}$ \\
\hline
\end{tabular}

There is no significant difference in numbers with similar letters $(\mathrm{p}<0.05)$.

\section{Discussion}

With regard to obtained results, the triglyceride and cholesterol levels in treatment groups showed significant decrease than the control group $(p<0.05)$ that this decrease was more significant in the group that received more amount of the essence. Therefore it can be concluded that the effect of the Ziziphora tenuior L. essence on level of the triglyceride and cholesterol factors depends on the dosage. The Ziziphora tenuior L. plant contains the essential oil that its ingredients are thymol and Carvacrol. Carvacrol decreases the plasma triglyceride concentration (Lee et al., 2003). Case et al. (1995) showed that Thymol and Carvacrol at doses of 0.15 (V/V) decreased the serum cholesterol in Leghorn chickens (Case et al., 1995). Elson and Qureshi (1995) showed that hypocholesterolemic effects of the Thymol and Carvacrol is related to the inhibition of the enzyme HMG_COA reductase (Elson \& Qureshi, 1955). Tsherich (2000) reported that using the Carvacrol stimulates the lactobacillus reproduction and growth. Lactobacillus has the important role in improvement of blood factors and decreasing serum lipids (Tschirch, 2000). Also perkival reported that lactobacilli can metabolize and absorb the cholesterol in the Small intestine and decrease its absorption through the blood (Percival, 2001). Cerig (1999) also reported role of medicinal plants and effective oils in decreasing cholesterol and protecting against the cancer (Craig, 1999). Also the serum cholesterol concentration was shown by adding the effective oils in the livery of broilers (Case et al., 1995) that obtained results in conducted research are consistent with the present study. Youshika et al. (2000) also reported that plant essential oils can decrease the abdominal fat deposition. This decrease can be caused by reduction of serum lipids (Yoshioka et al., 2000). Phenolic compounds available in medicinal plants control activity of the (HMG_COA) enzyme and in result the cholesterol synthesis is controlled. This act increases LDL receptors in surface of liver cells and consequently the LDL catabolism is accelerated. Inhibitors of HMG_COA reductase decrease the LDL and the plasma triglyceride concentration to a lower concentration (Barreto et al., 2008). In the present study a relative decrease was observed in the LDL amount in the group receiving the 400 $\mathrm{mg} / \mathrm{kg}$ doses of the Ziziphora tenuior L. essence. In this study enzymes serum ALT and AST were used to investigate the liver performance biochemistry. These enzymes naturally are existed in liver cells and these enzymes are released into the blood due to disorder in the plasma membrane or cells deposition when liver cells are damaged and so serum levels of these enzymes are increased. Therefore increased concentration of these two enzymes is considered as a suitable criterion for evaluating the level of the damage to liver cells (Chidambarama \& Carani, 2010). In the conducted study the ALT level in both treatment groups showed the significant decrease than 
the control group that this decrease was more in the second group that had received $400 \mathrm{mg} / \mathrm{kg}$ of the plant essence. So it can be said that the plant essence depends on the dose in causing the decrease in ALT and has no toxic effects on liver cells in doses of 200 and $400 \mathrm{mg} / \mathrm{kg}$ but improve the liver activity. Also the AST level in both treatment groups showed the relative decrease than the control group.

\section{References}

Al-Rawashdeh, I. M. (2011). Molecular Taxonomy Among Mentha spicata, Mentha longifolia and Ziziphora tenuior Populations using the RAPD Technique. Jordan Journal of Biological Sciences, 4(2), 63-70.

Amanlou, M. D., Dadkhah, F., Salehniak, A., \& Farsam. H. (2005). An antinocieptive effect of hydro alcoholic extract of satureje khuzestanica jamzad extract. The Journal of Pharmaceutical Sciences, 8(1), 102-106.

Barreto, M. S. R., Menten, J. F. M., Racanicci, A. M. C., Pereira, P. W. Z., \& Rizzo, P. V. (2008). Plant extracts used as Growth promoters in Broilers . Brazilian Journal of Poultry Science, 10(2), 109-115.

British Pharmacopoeia. (1988). British pharmacopoeia (Vol. 2, pp. 137-138). London: HMSO.

Case, G. L., He, L., Mo, H., \& Elson, C. E. (1995). Induction of geranyl pyrophosphate pyrophsphatase activity by cholesterol suppressive iso pre noids. Lipids, 30, 357-359. http://dx.doi.org/10.1007/BF02536045

Chidambarama, J., \& Carani, V. A. (2010). Cissus quadrangularis stem alleviates insulin resistance, oxidative injury and fatty liver disease in rats fed high fat plus fructose diet. Food and Chemical Toxicology, 48(8-9), 2021-2029. http://dx.doi.org/10.1016/j.fct.2010.04.044

Craig, W. G. (1999). Health promoting properties of common herbs. The American Journal of Clinical Nutrition, 70, 491-499.

Darbandia, T., Honarvarb, B., Sinaei, N. M., \& Rezaei, A. (2013). Extraction of Ziziphora tenuior essential oil using supercritical $\mathrm{CO}_{2}$. European Journal of Experimental Biology, 3(3), 687-695.

Elson, C. E., \& Qureshi, A. A. (1955). Coupling the cholesterol and tumor suppressive actions of palm oil to the impact of this minor Constituents on 3-hydroxy-3-methyl glutaryl coenzymeA reductase activity. prostaglandins Leukorrienes and Essential Fatty Acids, 852, 205-280.

Ghassemi, N., Ghanadian, M., Ghaemmaghami, L., \& Kiani, H. (2013). Development of a Validated HPLC/Photodiode Array Method for the Determination of Isomenthone in the Aerial Parts of Ziziphora tenuior L. Jundishapur J Nat Pharm Prod, 8(4), 180-186.

Karimi, I., Hayatgheybi, H., Motamedi, S., Naseri, D., Shamspur, T., Afzali, D., \& Hassanpour, A. A. (2013). Chemical Composition and Hypolipidemic Effects of an Aromatic Water of Ziziphora tenuior L. in Cholesterol-fed Rabbits. Journal of Applied Biological Sciences, 7(3), 61-67.

Lee, K. W., Evert, H., Kappert, H. G., Ferehner, M., Losa, R., \& Beynen, A. C. (2003). Effect of dietary essential oils on growth performance, digestive enzymens and lipid metabolism in femaile broiler chiken. British Poultry Science, 44, 450-457. http://dx.doi.org/10.1080/0007166031000085508

Naeini, A., Khosravi, A. R., Chitsaz, M., Shokri, H., \& Kamlnejad, M. (2009). Anti- Candida albicans activity of some Iranian plants used in traditional medicine. Journal of Medical Mycology, 19(3), 168-72. http://dx.doi.org/10.1016/j.mycmed.2009.04.004

Percival, M. (2001). Choosing a probiotic supplement. Clinical nutrition Insights. Advances in Nutrition, 6, 1-9.

Sharafzadeh, S., \& Alizadeh, O. (2012). Some Medicinal Plants Cultivated in Iran. Journal of Applied Pharmaceutical Science, 2(1), 134-137.

Tabatabaei, Y. F., Mortazavi, A., Koocheki, A., Afsharian, S. H., \& Alizadeh, B. B. (2013). Antimicrobial properties of plant extracts of Thymus vulgaris L., Ziziphora tenuior L. and Mentha Spicata L., against important foodborne pathogens in vitro. Scientific Journal of Microbiology, 2(2), 23-30.

Talebi, S. M., Rezakhanlou, A., \& Salahi, I. G. (2012). Trichomes Plasticity in Ziziphora tenuior L. (Labiatae) in Iran: An ecological review. Annals of Biological Research, 3(1), 668-672.

Tschirch, H. (2000). The use of natural plants extracts as production inhansers in modern animal rearing practiees. Zeszyty Naukowe Akademii Rolniczej Wroclaw, Zootechnika, XXV376, 25-39.

Verdian-Rivi, M. (2008). Effect of the Essential Oil Composition and biological activity of Ziziphora clinopodiodes Lam. on the against Anopheles Stephensi and Culex pipiens Parva from Iran. Saudi Journal of Biological Sciences, 15(1), 185-188. 
Yoshioka, M., Matsuo, T., Link, T. A., \& Suzuki, M. (2000). Effect of capsaicin on abdominal fat and serum free fatty acids in exercise_trained rats. Nutrition Research, 20, 1041-1045. http://dx.doi.org/10.1016/S0271-5317(00)00180-9

\section{Copyrights}

Copyright for this article is retained by the author(s), with first publication rights granted to the journal.

This is an open-access article distributed under the terms and conditions of the Creative Commons Attribution license (http://creativecommons.org/licenses/by/3.0/). 